\title{
The Critical Barrier
}

\section{to Civil War Settlement}

\author{
Barbara F. Walter
}

\section{Introduction}

Unlike interstate wars, civil wars rarely end in negotiated settlements. Between 1940 and 199055 percent of interstate wars were resolved at the bargaining table, whereas only 20 percent of civil wars reached similar solutions. ${ }^{1}$ Instead, most internal wars ended with the extermination, expulsion, or capitulation of the losing side. In fact, groups fighting civil wars almost always chose to fight to the finish unless an outside power stepped in to guarantee a peace agreement. If a third party agreed to enforce the terms of a peace treaty, negotiations always succeeded regardless of the initial goals, ideology, or ethnicity of the participants. If a third party did not intervene, these talks usually failed.

The fact that civil wars tend to end on the battlefield poses a startling empirical puzzle for political scientists and an increasingly onerous problem for policymakers. Why are domestic enemies unable to negotiate successfully? And what can the international community do to help end these conflicts?

I argue that civil war negotiations rarely end in successful peace settlements because credible guarantees on the terms of the settlement are almost impossible to arrange by the combatants themselves. Negotiations do not fail because indivisible stakes, irreconcilable differences, or high cost tolerances make compromise impossible, as many people argue. They do not fail because bargains cannot be struck. Adversaries often compromise on the basic issues underlying their conflict, and they frequently find mutually acceptable solutions to their problems. Negotiations fail because civil war opponents are asked to do what they consider unthinkable. At a

My thanks to Richard Betts, Jim Fearon, Hein Goemans, Zoltan Hajnal, Robert Jervis, David Laitin, Gideon Rose, Jack Snyder, Stephen Walt, and participants at seminars at the University of Chicago, the Olin Institute for Strategic Studies at Harvard University, and the War and Peace Institute at Columbia University for their helpful comments on various drafts. I also gratefully acknowledge the financial support of the Harry Frank Guggenheim Foundation and the Andrew W. Mellon Foundation.

1. This phenomenon has been documented by a number of authors. See Modelski 1964; Pillar 1983; and Stedman 1991. 
time when no legitimate government and no legal institutions exist to enforce a contract, they are asked to demobilize, disarm, and disengage their military forces and prepare for peace. But once they lay down their weapons and begin to integrate their separate assets into a new united state, it becomes almost impossible to either enforce future cooperation or survive attack. In the end, negotiations fail because civil war adversaries cannot credibly promise to abide by such dangerous terms. Only when an outside enforcer steps in to guarantee the terms do commitments to disarm and share political power become believable. Only then does cooperation become possible.

In this article I have two aims. First, I propose a theory of civil war resolution that rests on reciprocal problems of enforcement and vulnerability rather than on innate differences, goals, or greed. My purpose is to dispel currently popular notions that civil wars are either beyond compromise or only amenable to compromise when accompanied by a military stalemate and exceptionally skilled mediation. Second, I systematically test current theories against forty-one civil war cases. I conclude by presenting the conditions under which negotiated solutions, once reached, can be implemented and maintained and the crucial role that outside intervention can play in resolving these conflicts.

The first section of this article presents a theory of civil war termination: domestic adversaries rarely settle off the battlefield because any attempt to end a civil war will also eliminate any self-enforcing strategies to maintain the peace. The second section explores four alternative theories that focus on high costs, indivisible stakes, bargaining problems, and group identity as the key variables affecting resolution. The third section explains how cases were selected and coded and outlines the steps taken to test the competing hypotheses. The fourth section interprets the findings and discusses what they suggest about foreign involvement in internal wars.

\section{The Puzzle}

Ending a war is usually difficult. Organizational inertia, tunnel vision, wishful thinking, and miscommunication all work against early reconciliation and make cooperation difficult. Once fighting begins, plans are set in motion and attitudes toward the enemy become fixed in ways that are not easily reversible. ${ }^{2}$ Even if opponents agree to negotiate, they still face the risks and uncertainties of cooperation. Will an opponent fulfill its side of the agreement? Or will the compromise itself turn out to be an inherently bad deal?

Despite these obstacles, international wars usually end with some type of explicit settlement. Civil wars do not. Current explanations claim that power asymmetries, indivisible stakes, bargaining difficulties, or opposing identities make settlement in civil wars nearly impossible. But this seems unlikely. Military stalemates often emerge in civil wars without prompting negotiations; governments can be shared by more

2. For an in-depth discussion on the difficulties in ending wars, see Ikle 1991. 
than one party; and groups that appear ethnically or religiously incompatible do meet to discuss alternative solutions to war.

Others argue that groups are stuck in what could be called a game of deadlock; cooperation is impossible because competing domestic groups will always have opposing preferences and interests. But this also seems unlikely. Civil war adversaries do not always continue to fight because they cannot arrange compromise settlements. Between 1940 and 199042 percent of civil wars (seventeen out of forty-one) experienced some form of formal peace negotiation, and 94 percent of these cases drafted at least a cease-fire accord. ${ }^{3}$ In other words, adversaries often attempted very serious peace talks that then broke down. In short, none of the current explanations identifies a compelling reason why domestic enemies would forgo negotiations in favor of potentially lengthy battlefield contests. What follows is an attempt to identify additional factors that might inhibit successful civil war resolution and cause even promising negotiations to cycle back into war.

\section{The Theory}

\section{What is Different About Civil Wars?}

The key difference between interstate and civil war negotiations is that adversaries in a civil war cannot retain separate, independent armed forces if they agree to settle their differences. This difference fundamentally alters incentives to abide by any peace treaty and makes it almost impossible for groups to cooperate. In the following section, I argue that groups fighting civil wars avoid negotiated settlements because they understand that this would require them to relinquish important fall-back defenses at a time when no neutral police force and no legitimate government exist to help them enforce the peace. Knowing they will enter a period of intense vulnerability, neither side can convince the other that they will nobly resist a treaty's temptations or naively fulfill its terms. And so, unable to enforce the agreement or survive exploitation, they avoid cooperation and continue to fight.

Interstate Cooperation Under Anarchy Encouraging and then maintaining cooperation under anarchy is not easy. It is especially difficult in "prisoners' dilemma" situations where both states would benefit from cooperating but would also be far worse off if they naively cooperated while their opponent exploited their trust. ${ }^{4}$

States in the international system have devised a number of military and economic strategies to encourage cooperation even when incentives favor cheating. They can create early warning systems and sophisticated monitoring and verification procedures to check each other's behavior. They can build military defenses, forge external alliances, and set up buffer zones to make aggression more costly. They can also

3. See Table 1.

4. The following are indispensable readings for those interested in the strategic dilemmas associated with cooperation under anarchy: Jervis 1978 and 1976, especially chap. 3; and Schelling 1966, chap. 6. For applications of these theories to the causes of war, see Posen 1993, 103-24. 
use symbiotic trade relationships, side-payments, and economic coercion to enhance the rewards from cooperation. They can also withhold key resources or use reciprocal punishment strategies to ensure that violations are punished. Each of these strategies helps to create binding agreements.

Nonetheless, even the most sophisticated strategies for ensuring compliance are not foolproof, and states know this. States will, however, often cooperate despite this risk if they can limit the damage caused by cheating. A surprise attack might renew the war, but states with strong defenses and active forces would be no worse off than before the settlement. In fact, states could use this time to refurbish forces and restock supplies and thus increase their security. Under these conditions, the risks of exploitation are manageable and well worth the potential benefits of long-term peace.

Domestic Cooperation Under Anarchy None of these strategies is available to groups fighting civil wars. Although the same anarchic conditions exist during times of civil war as those that exist permanently in the international system-no central government exists to insure order, no police or judicial system remains to enforce contracts, and groups have divided into independent armed camps - the pernicious effects of anarchy are actually far more severe. Whereas interstate opponents can augment the benefits of cooperation and sharpen punishments for cheating, civil war adversaries have little ability to do so. If they wish to cooperate, these groups must disband their forces and, in so doing, relinquish their only remaining means for protection. Even states that surrender unconditionally are rarely required to go so far. ${ }^{5}$

Thus the single most detrimental condition operating against cooperation is that civil war adversaries cannot maintain independent armed forces if they decide to reconcile. Once they sign a peace treaty they cannot retreat to their own borders and defensively reinforce their militaries, they do not become trading partners or important allies, and they cannot hide behind buffer zones. Only if they are willing to relinquish control over occupied regions, vital industries, and independent military organizations is a cooperative peace agreement possible.

This situation forces governments and rebels into a paradoxical and unfortunate dilemma. Any attempt to end a civil war and unify the country also eliminates any ability to enforce and ensure the peace. Thus, the only way enemies in a civil war can prematurely end the bloodshed is to force themselves through a transition period during which they can neither encourage cooperation nor survive attack. They must weather a period of extreme vulnerability. Civil war rivals, therefore, are damned if they do and damned if they don't. As soon as they comply with a peace treaty they become powerless to enforce the terms over which they had bargained so hard.

The fact that settlement can leave a group far worse off than it would have been had it simply continued to fight has two devastating effects on cooperation. First, it discredits any promise to abide by the terms of an agreement even if offered in good

5. Even mandatory force reductions usually included in international peace treaties do not leave the adversaries defenseless. 
faith, and, second, it increases groups' anxiety about future security and makes them hypersensitive to even the smallest treaty violation.

The result? In most cases the government and the rebels will recognize the overwhelming risks involved with compliance, and they will refuse to sign any treaty even if all the underlying issues have been resolved and even if both sides sincerely want peace. If they do sign, this fear and insecurity will become so overwhelming that even satisfactory settlements will slowly unravel. In his 1949 report on China, Dean Acheson keenly observed that " $[\mathrm{t}]$ he distrust of the leaders of both the Nationalist and Communist Parties for each other proved too deep-seated to permit final agreement, notwithstanding temporary truces and apparently promising negotiations." ${ }^{6}$ Since each side understands the profits to be gained by exploiting a peace treaty (and both sides know that their opponent also recognizes this opportunity), their promises to honor and respect the terms of the agreement cannot be trusted. Under these conditions, fighting suddenly appears far more appealing than settlement.

In the end, negotiated settlements in civil wars perish under their own unique demands. Incumbent governments and rebels cannot structure the agreement so that it will, at worst, allow each side to return as close as possible to the status quo should one party decide to cheat. And as long as both factions understand that cooperation will leave them vulnerable and they have no means to avoid this condition, they will prefer to continue fighting rather than risk possible attack.

But could more stable, less risky transitions be designed by the participants themselves? For example, if the government and the rebels fear a one-step advantage, could military integration occur in a step-by-step or reciprocal fashion? Or, if one side enjoys a preponderance of military power and its opponent enjoys a preponderance of political support (like the Kuomintang and the Communists in China), could these opposing strengths deter the breakdown of a settlement? And finally, could groups agree to remain armed until all obtained some real control over new government institutions and national security forces? This would impart some protection until more appropriate institutional checks and balances could be established.

Stable, less risky transitions cannot be designed by the participants themselves for three reasons that are tied to problems of credible commitment. ${ }^{7}$ First, groups will have great difficulty convincing each other to fully execute any plan that eventually requires them to disarm. Although numerous implementation plans can be designed to reduce vulnerability, in the end even the most incremental and impartial one will require the full demobilization of partisan groups. In civil wars, disarmament can be postponed, and it can be done gradually and in a reciprocal manner, but it can never be avoided. And as long as a threshold exists beyond which unilateral defense is

6. "Dean Acheson's July 30, 1949, Letter of Transmittal to President Truman, The China White Paper, Department of State Publication 3573," Far Eastern Series 30 (Stanford: Stanford University Press, 1949), xv.

7. The problem of credible commitment is not new in the international relations literature. For other discussions related to ethnic conflict, see Fearon 1993; Weingast 1994; Fearon 1995; and Lake and Rothchild 1996. 
impossible, and both groups realize that an opponent need only wait for this time to attack, they will either avoid compliance altogether or simply renege on further fulfillment at the first sign of default. Second, groups will also have great difficulty convincing each other to accept any plan that offers even the slightest chance of annihilation. ${ }^{8}$ A 95 percent risk-free disarmament plan might appear perfectly acceptable on paper, but to the groups involved, even a slight chance of an attack is often too high. In situations of extreme vulnerability, the beliefs groups have about their own safety and their perception of threat matter as much if not more than the actual invulnerability of the treaty design. Finally, groups will also have a difficult time using new institutions to project a credible promise of either effective protection or neutral enforcement during the transition. These institutions are new and untested. They are often designed by "democratic novices" - people inexperienced with multiparty political systems, opposition groups, and peaceful transfers of power. Moreover, these institutions will initially be staffed by former government and rebel officials with lingering partisan loyalties. These institutions might eventually serve to reassure groups that their rights and liberties will be protected, but when new, they could just as well be used as instruments for further repression. Reassuring they are not.

The Importance of Third-Party Guarantees Third-party guarantors can change the level of fear and insecurity that accompanies treaty implementation and thus facilitate settlement. An important and frequent reason why opponents fail to reach successful settlements is because they cannot credibly commit to an agreement that will become far less attractive once implemented. Third parties, however, can guarantee that groups will be protected, terms will be fulfilled, and promises will be kept (or at least they can ensure that groups will survive until a new government and a new national military is formed). In short, they can ensure that the payoffs from cheating on a civil war agreement no longer exceed the payoffs from faithfully executing its terms. Once cheating becomes difficult and costly, promises to cooperate gain credibility and cooperation becomes more likely.

But how does one ensure that promises made by a third party at the negotiating table are themselves credible? To be credible, a guarantee must fulfill at least three basic conditions. First, the outside state must have a self-interest in upholding its promise. ${ }^{9}$ Old colonial ties, strategic interests, economic investments, or alliance loyalties will enhance any commitment to intervene and will indicate the political will to persevere. Second, the guarantor must be willing to use force if necessary, and its military capabilities must be sufficient to punish whichever side violates the treaty. Syria could occupy Lebanon, Britain overshadowed Zimbabwe, Ethiopia dwarfed Sudan, and the United States could restrain the Dominican Republic. Equal or greater force is necessary for any threat to effectively deter cheating. Third, the intervening

8. For an excellent discussion of the problem of intense vulnerability on cooperation, see Weingast 1994.

9. See Touval and Zartman 1985, 258-60. 
state should be able to signal resolve. The outside power can either station sufficient forces to deter aggression without having to send for additional forces if conflict breaks out, as Syria did in Lebanon. Or it can create some type of military trip wire, as Britain did in Zimbabwe. Outside forces can also be placed at strategically important locations, such as troop assembly areas, borders, or munitions sites, and guarantors can have pre-approval from home governments for further action. These costly signals should allow states to reveal their true preferences and enhance the credibility of their promises. ${ }^{10}$

The credible-commitment theory of civil war resolution, therefore, offers us our first hypothesis for testing. Given the reciprocal problems of enforcement and vulnerability, hypothesis 1 predicts that the more willing an outside power is to guarantee the safety of the adversaries during the critical implementation phase, the more likely domestic opponents are to reach and execute a final deal. ${ }^{11}$ If no such guarantee exists, civil wars should either fail to reach a settlement or such settlements should quickly break down. Seen in this light, it becomes clear why Sudan's Anya Nya rebels delayed signing the Addis Ababa agreement until Ethiopian Emperor Haile Selassie personally guaranteed their safety during its implementation. It also explains why the UNITA rebels in Angola refused to "start demobilising [their] troops until a 12,000-strong UN peacekeeping force was in place." 12 The consequences of being duped were too great to risk.

\section{Alternative Explanationsfor Why Civil Wars End Decisively}

Few alternative explanations exist for why civil wars tend to end decisively. Civil war termination, for the most part, is not viewed as an independent puzzle in need of explanation. Most scholars have either ignored the entire topic of civil war resolution or have argued that civil wars are largely irreconcilable and therefore uninteresting to study from a war termination perspective. Compromise has been seen as virtually impossible.

The discrepancy between civil and interstate war resolution, however, has recently attracted the attention of a number of scholars. Although most authors mix and match explanatory variables, their theories can be broken down into two basic schools. The rationalist school believes that enemies in civil wars are driven by the same cost calculations as their interstate peers but are plagued with special problems that make agreement difficult. ${ }^{13}$ The ideational school, on the other hand, views civil wars as uniquely emotional and value-laden conflicts that naturally shun compromise. ${ }^{14}$

10. For discussions on signalling see Fearon 1994; Jervis 1989, especially chap. 4; and Kydd 1996.

11. This is not to say that outside guarantees can end a war that the combatants have no desire to end. If continued fighting is more favorable than the terms of any possible peace settlement, an outside guarantee will not alter the cost and benefits enough to convince the opponents to cooperate. Outside guarantees will only be effective in cases where the adversaries are themselves seeking an alternative to continued war.

12. “Talks End, War Goes On,” The Economist, 29 May 1993, 45.

13. See Mason and Fett 1996; Wagner 1993; Zartman 1993; and Holl 1993.

14. See Randle 1973, especially 430; Horowitz 1985, especially chap. 14; and Burton $1987 \mathrm{~b}$. 
Rationalist explanations argue that domestic opponents will make the same costbenefit calculations that independent states do before agreeing to sign a peace treaty. They will carefully estimate their chances of winning, the amount of time it will take to achieve this victory, how much it will cost, and their relative payoff from winning versus accepting a settlement. In other words, domestic groups will only settle if they believe they could do no better by either continuing to fight or continuing to bargain.

But if domestic adversaries make the same cost calculations as their interstate counterparts, why do fewer negotiated settlements occur in civil wars? Three possible explanations are offered to explain this discrepancy. The first variant argues that negotiated settlements are so rare because the benefits of winning a civil war are so much greater. ${ }^{15} \mathrm{~A}$ decisive win would not only give the victor full control of the state, it would also permanently eliminate a rival for limited resources. Decisive victory, therefore, offers both immediate and long-term returns for which adversaries are willing to incur far greater costs. As Jane Holl has argued, "The intensity or duration of combat may be excessive because belligerents value the shape of the settlement more than the costs of disagreement." 16

Supporters of the second variant argue that domestic stakes are either difficult or impossible to divide, and this makes a shared settlement infeasible. ${ }^{17}$ Fighting until the end is more likely in civil wars because only one legitimate government and one legitimate military force can exist at any one time. "If," as Fred Ikle argues, "partition is not a feasible outcome because the belligerents are not geographically separable, one side has to get all, or nearly so, since there cannot be two governments ruling over one country, and since the passions aroused and the political cleavages opened render a sharing of power unworkable." 18

The final rationalist approach emphasizes the difficulties in reaching a mutually acceptable bargain in wars where barriers to negotiation are high and bargaining problems particularly exacting. These explanations argue that extremist demands, ambitious leaders, poor communication, fear, and erratic outside aid limit the range of tolerable solutions and make mutually acceptable bargains difficult to locate. The trick is to find terms agreeable to both parties under what are always difficult bargaining conditions. Supporters argue that "an extremely subtle and sensitive approach" is often required to overcome these problems, and they identify mediation as the key to success. If a highly skilled problem solver emerges to help overcome these pitfalls, talks will succeed. ${ }^{19}$ If a deft mediator cannot assist, negotiations will most likely fail.

Three hypotheses can be drawn from the preceding arguments. The first (hypothesis 2) predicts that successful settlements should be more likely as the expected costs of winning a war increase. Hypothesis 3 predicts that adversaries are more

15. See Mitchell 1991; Assefa 1987; Stedman 1991; and Zartman 1989 and 1993.

16. Holl 1993, 277.

17. See Pillar 1983, 24; Ikle 1991, 95; Holl 1993, 275; Modelski 1964; and Bell 1972, 218.

18. Ikle 1991,95 .

19. Assefa 1987,29. See also Stedman 1991,23-24; Modelski 1964, 143; Assefa 1987, 17-29;Zartman 1989; Rothchild and Hartzell 1993; Low 1985. 
likely to settle in wars where the stakes are easy to divide, such as in secessionist wars where groups demand territory and not state control. Hypothesis 4 predicts that the greater the skill of the mediator, the greater the likelihood for successful settlement.

Scholars in the ideational school see things differently. Internal conflicts, in their view, are far less rationally motivated than wars between independent states. Unlike interstate struggles that are often driven by greed or a desire for dominance, civil wars are seen as intense value conflicts fought over issues closer to the heart. Domestic conflicts are believed to "involve deep issues of ethnic and cultural identity, of recognition, and of participation that are usually denied to ethnic minorities, in addition to ... other values that are not negotiable." ${ }^{20}$ Compromise is more difficult under these conditions because groups often cannot find common ground. Hypothesis 5 , therefore, predicts that wars fought over issues tied to the identity of the participants would be more difficult to resolve than those fought over more malleable political or economic issues.

\section{Data}

Cases

I tested these competing hypotheses against every civil war between 1940 and $1990 .{ }^{21}$ Cases were selected based on the coding criteria proposed by J. David Singer and Melvin Small's Correlates of War project. To be included in the set of all civil wars a conflict had to (1) generate at least one thousand battle deaths per year, (2) occur within a generally recognized boundary, (3) involve the national government as a principal agent, and (4) experience effective resistance from both the rebels and the government. ${ }^{22}$ These cases are listed in Table 1.

The forty-one civil wars that met these criteria were then further distinguished by two questions: (1) Did negotiations occur during the war? (2) Did these negotiations then end in a successful settlement or did the war continue until either the government or the rebels won a decisive victory? This distinction was made to differentiate

20. Burton $1987 \mathrm{a}$.

21. The fifty-year time span was chosen in order to include a large enough set of cases to apply statistical analysis. It was bounded in 1990 to determine whether or not settlements would last at least five years.

22. Critics of Singer and Small's dataset have argued that their coding criteria are excessively broad (see Pillar 1983; Stedman 1991; and Licklider 1993). As a result, many small-scale confrontations, such as riots or coups, are included that do not merit the more momentous "civil war" status. To account for this criticism two case lists were constructed for testing: one generated by Singer and Small's broad definition of civil war and one that excluded any borderline cases. Cases with fewer than fifteen hundred total battle deaths (such as Guatemala in 1954 and 1970-71, and Indonesia in 1953) or conflicts restricted to a very small percentage of the population (power struggles within the military or a purge within the government) were dropped. The competing hypotheses were then tested against both lists. Since no significant differences were found between the two case lists, the broader list was used in all subsequent analysis. Borderline cases are indicated in Table 1 with a superscript " $b$ ". 
those wars where the combatants actively pursued a settlement from those where at least one combatant appeared unwilling to find a middle ground.

A war was coded as having experienced negotiations if both sides had enough bargaining power to elicit important concessions from each other, if factions actually held face-to-face talks, if issues relevant to resolving the war were discussed, and if talks appeared to be undertaken in good faith. These qualifications eliminated scheduled talks that never took place, meetings where no substantive issues were discussed, and talks that excluded key participants in the war. Attempts were also made to exclude meetings undertaken in bad faith. ${ }^{23}$ A readiness to accept supervision, public announcements of important concessions, a desire to discuss the details of a transfer of power, and long-term participation in lengthy negotiations all generated costs to the rivals and indicated more than a tactical interest in appearing cooperative. This qualification helped exclude bogus meetings where delegates refused to talk to each other, set ridiculous preconditions, stalled for time, or feigned interest. Picking only those talks that had any chance for success ensured a tough test of the hypotheses; the more likely talks were to succeed on their own, the less likely it was that high costs, mediation, or outside guarantees had any independent effect on the outcome.

A distinction was also made between negotiations that took place between relative equals and those negotiations that occurred after one side essentially won the war. Although bargaining did sometimes occur even when one side accepted defeat, as it did between King Hussein and the Palestinian Liberation Organization in 1970, such one-sided talks could not fairly be classified as negotiations aimed at ending a war short of conquest. If one side had essentially lost, and discussions were merely over when and how the other side would take over, such talks were not classified as negotiations.

Civil wars were then classified according to outcome. Did the war end decisively, or did it end with some form of successful compromise solution? A war was defined as a "decisive victory" if one side could convince its opponent(s) to cease fighting without demanding any major concessions in return. Although it is fairly common that even decisive military victories end with some form of "negotiated" agreement, an important distinction was once again made between contests that ended with an agreement negotiated by groups with sufficient strength to continue organized military resistance and an agreement that was imposed with little discussion or modification by one side or the other, and only the former were classified as true "negotiations."

Successful settlements, therefore, were coded on the basis of three criteria. First, a treaty had to be jointly drafted by all combatants through give-and-take bargaining. ${ }^{24}$

23. This was sometimes difficult to determine since belligerents often tried to appear inflexible during discussions ostensibly to maximize any bargaining power. This could explain why participants in so many cases stubbornly asserted that they would never compromise, only to agree to major concessions later. Certain actions, however, did help reveal whether or not the participants sincerely wished to cooperate.

24. The final product could be written or tacit. In rare cases, such as Yemen, 1970, warring factions bargained for and agreed to very specific political and military arrangements that remained strictly verbal. 
Once again, this did not include agreements signed by both parties that were only the final part of the war termination process. These "settlements" were more aptly defined as capitulations or surrenders, not as substantive agreements over future political and military arrangements. ${ }^{25}$ Second, the agreement had to keep the opposition intact as a bargaining entity. Third, it had to end the war for at least five years. ${ }^{26}$ If a formal peace treaty was signed but broke down within this time period, it was considered a failed attempt, and the outcome in these cases was coded on the basis of the eventual military results. Although peace treaties were signed in Uganda (December 1985), Laos (February 1973), Vietnam (January 1973), Jordan (September 1970), Greece (February 1945), China (January-February 1946), and Chad (March 1979 and August 1979), the terms were either never implemented or only partially implemented, and all broke down within a year. All eventually ended in a decisive victory for either the government or the rebels. Requiring a peace treaty to last at least five years ensured that only those settlements with lasting effects were coded as successful. This coding was then checked against those presented by Roy Licklider, Hugh Miall, and Paul Pillar in their datasets. ${ }^{27}$ Table 1 lists all the wars included in the study and their eventual outcome. ${ }^{28}$

\section{Coding the Hypotheses ${ }^{29}$}

Since civil wars can end either in a decisive victory or in a bargained treaty, the dependent variable in each case was coded dichotomously as either decisive victory or successful settlement. ${ }^{30}$

The independent variables were coded as follows. Hypothesis 1 posited that successful negotiations to civil wars would vary directly with the strength of outside security guarantees. Third-party security guarantees were defined as any implicit or explicit promise given by an outside power to protect adversaries during the treaty implementation period. ${ }^{31}$ Such guarantees were then broken down into three levels of strength: weak, moderate, or strong. A guarantee was coded as "weak" if it included

25. It would be misleading and inaccurate to include these cases as successfully negotiated settlements.

26. A five-year measure was chosen to see if a settlement would survive the first general election. It is also the most widely used indicator in the literature. This stipulation excluded some recent, wellpublicized wars, such as Mozambique, El Salvador, Cambodia, and Bosnia, whose peace treaties have not yet met the five-year durability standard. If robust, the findings should still apply to these cases.

27. Licklider 1995; Miall 1992; and Pillar 1983.

28. The full dataset has not been reprinted due to space restrictions but is available to other scholars from the author.

29. Coding for all variables was made on the basis of primary and secondary historical sources.

30. I did not distinguish among "successful settlement," "failed settlement," and "decisive victory" because failed settlements eventually ended in a decisive victory for one group or the other.

31. Promises did not always have to be voiced explicitly. No one questioned the United States' mission in Lebanon in 1958 when approximately fourteen thousand U.S. troops were stationed there, or Syria's resoluteness in 1976 when it sent a "deterrent" force of thirty thousand to Lebanon. Such an enormous commitment of troops was considered a credible threat to act even if the rules of engagement remained vague. 
Table 1. Civil wars ending 1940-90

Civil war

1. China $(1946-49)^{\mathrm{a}}$

2. Paraguay (1947)

3. Greece $(1944-49)^{\mathrm{a}}$

4. Yemen $(1948)^{\mathrm{b}}$

5. Costa Rica (1948)

6. Colombia (1948-58)a, c

7. Burma (1948-51)

8. Indonesia (1950)

9. Philippines (1950-52)

10. Bolivia (1952) ${ }^{\mathrm{b}}$

11. Indonesia $(1953)^{\mathrm{b}}$

12. Guatemala $(1954)^{b}$

13. Argentina $(1955)^{b}$

14. Indonesia (1956-60)

15. Lebanon (1958) a

16. Cuba (1958-59)

17. Iraq $(1959)^{\mathrm{b}}$

18. Vietnam $(1960-75)^{\mathrm{a}}$

19. Congo (1960-65)

20. Laos $(1960-75)^{\mathrm{a}}$

21. Algeria (1962-63)

22. Yemen $(1962-70)^{\mathrm{a}}$

23. Sudan (1963-72) ${ }^{\mathrm{a}}$

24. Rwanda (1963-64)

25. Dominican Rep. $(1965)^{\mathrm{a}}$

26. Uganda (1966) ${ }^{\mathrm{b}}$

27. China $(1967-68)^{\mathrm{b}}$

28. Nigeria (1967-70)

29. Cambodia (1970-75)

30. Jordan $(1970)^{\mathrm{a}}$

31. Guatemala (1970-71)

32. Pakistan (1971)

33. Sri Lanka (1971)

35. Rhodesia (1972-79)a

36. Lebanon (1975-76) ${ }^{\mathrm{a}}$

37. Iran (1978-79)

38. Nicaragua (1978-79) ${ }^{\mathrm{a}}$

39. Uganda $(1981-87)^{\mathrm{d}}$

40. Chad (1979-87)

41. Nicaragua (1981-89)a
Negotiations

Outcome

Decisive victory (rebels)

Decisive victory (government)

Decisive victory (government)

Decisive victory (rebels)

Decisive victory (rebels)

Settlement succeeded

Decisive victory (government)

Decisive victory (government)

Decisive victory (government)

Decisive victory (rebels)

Decisive victory (government)

Decisive victory (rebels)

Decisive victory (rebels)

Decisive victory (government)

Settlement succeeded

Decisive victory (rebels)

Decisive victory (government)

Decisive victory (rebels)

Decisive victory (government)

Decisive victory (rebels)

Decisive victory (rebels)

Settlement succeeded

Settlement succeeded

Decisive victory (government)

Settlement succeeded

Decisive victory (government)

Decisive victory (government)

Decisive victory (government)

Decisive victory (rebels)

Decisive victory (government)

Decisive victory(government)

Decisive victory (rebels)

Decisive victory (government)

Settlement succeeded

Settlement succeeded

Decisive victory (rebels)

Decisive victory (rebels)

Decisive victory (rebels)

Decisive victory (rebels)

Settlement succeeded

${ }^{a}$ Wars in which negotiations were attempted.

${ }^{b}$ Borderline cases (small-scale confrontations with less than fifteen hundred battle deaths).

cThe civil wars in Colombia and in Laos were broken into two phases by Singer and Small.

dThe civil wars in Uganda, Chad, and Nicaragua were not included in the Singer and Small dataset since they occurred after the study ended in 1980. 
only a formal promise to intervene should the treaty break down. Although no ground forces were required, this promise had to be offered publicly during formal negotiations by the leader of the guarantor state or his or her direct emissary. In other words, the promise had to be widely known and could not be recanted without negative reputational effects on the leader. A "moderate guarantee" required the deployment of at least five hundred soldiers prior to the implementation period. Although insufficient to pacify an aggressive attack, this commitment was seen as a credible deterrent given the visibility of the endorsement. An early withdrawal was viewed as potentially costly to the guarantor since it could severely damage "credibility with friends and allies," as President Clinton himself admitted when pressured to withdraw from Somalia. ${ }^{32}$ Finally, a promise was coded as a "strong guarantee" if an outside state sent massive ground forces (at least ten thousand) to the beleaguered country. This was viewed as an unambiguous and indisputable demonstration of intent. ${ }^{33}$

The most popular hypothesis, hypothesis 2 , claimed that opponents were increasingly likely to settle as the expected costs of achieving victory increased. This hypothesis was measured using four indicators: the duration of war, the presence of a military stalemate, the magnitude of war (measured in battle deaths per one thousand population), and the intensity of the war (measured in battle deaths per month). ${ }^{34}$ These indicators were seen as good yardsticks since domestic factions adjust their estimates on the likely costs of war as they obtain new information on the progress of battle. The duration of war, the number of battle deaths per population, and the number of battle deaths per month indicate how costly war has been and provide important information about what may lie ahead. The presence or absence of a military stalemate allows groups to estimate how long it might take before one side or the other could prevail on the battlefield. A military stalemate would indicate a balance of power between the competing groups and promise a long fight.

But how do you define "military stalemate"? As Licklider so aptly stated, "Zartman's concept of the 'hurting stalemate' is deceptively hard to work with.... The concept is difficult to operationalize without being tautological." ${ }^{35}$ The best definition I can offer is a situation where neither combatant is able to make noteworthy advances on the battlefield due to the strength of the opposing side, and neither side believes that the situation will improve in the near future. ${ }^{36}$ Although none of these measures is a perfect predictor of the future costs of war, taken together they should provide a fairly good estimate of group perceptions of the costs and benefits of continuing to fight.

32. New York Times, 8 October 1993, A15, quoted in Mercer 1996, 4-5.

33. Such massive involvement does somewhat muddy the waters between negotiated settlements reached by the parties themselves and settlements imposed by outside force. Massive ground forces were coded as a guarantee, however, if they brought peace to an otherwise war-torn state.

34. The measures for both "magnitude" and "intensity" were taken from the Correlates of War database. See Small and Singer 1982.

35. Licklider 1993, 309.

36. A similar definition is offered by Licklider 1993. The selection of cases was then checked against standard historical accounts. If disagreement arose, I deferred to the historical consensus. 
Hypothesis 3 predicted that the easier the stakes were to divide, the more likely opponents were to reach a settlement. "Divisibility" was first measured by identifying the goals of the combatants and then coding a conflict as "separatist" or "nonseparatist." A war was coded as separatist if a faction attempted to split from the original territory and create a new state or if it aimed to obtain greater regional autonomy. The widespread rebellions in Sumatra, Java, and the Moluccans in 1953, for example, were coded as separatist movements since rebel leaders sought greater home rule and a larger share of the national revenue, not political control. If the factions simply wanted to take over the existing government, the conflict was coded as nonseparatist. Separatist demands for territory were expected to be easier to meet than nonseparatist demands for state control and thus more likely to reach successful settlements.

Measuring "divisibility" using the goals of the belligerents, however, could be problematic. Separatist groups often have unrealistic demands that the government cannot satisfy without hurting the state's survival as a political entity. Secessionists might demand portions of territory that include most if not all of the valuable resources within the original state or demand self-determination in an already tenuous multiethnic state. Compromise under these conditions might be viewed as selfdestructive by the government and therefore unacceptable at any cost—not necessarily the best indicator of a government's desire to compromise in general.

A second measure of "divisibility" was therefore constructed based on the distribution of population and resources within each state, in other words, based on how easy it would be to actually divide the state. Division was considered "easy" if the fighting factions occupied distinct regions of the country and the resources were distributed fairly equally among them. The war between East and West Pakistan in 1971 and the rebellions in the Indonesian islands in the 1950s were wars where the stakes could have been easily divided. Division was considered "impossible" if the populations fighting the war were indistinguishable because the war was fought for political or economic reasons rather than ethnic or religious reasons or if the resources were concentrated in a single area occupied by one group. Greece, Colombia, Nicaragua, Argentina, Cambodia, and Laos were some of the cases included in this group. Divisibility was coded as "difficult" but not impossible if the population was interspersed together with the resources or if the population was concentrated into distinct regions with one region possessing most of the resources. Cases where separation would be easy were once again expected to reach settlement more often than cases where separation would be difficult, regardless of the original aims of the competing groups.

Hypothesis 4 had the most difficult variable to operationalize since it argued that mediation strategies and tactics must be tailored to the specifics of each case. Nonetheless, mediation can be partially tested by simply reporting how often a mediator was present during negotiations in each war. Given the theory, one would expect all successful settlements to involve mediation and those that failed to have suffered from its absence. 
Hypothesis 5 predicted that successful settlements would emerge less often in wars fought between competing identity groups. If a war broke down along ethnic or religious lines, it was considered to involve issues of identity and was coded as either "ethnic" or "religious." All other wars were coded as "nonidentity" conflicts. Ethnic or religious wars were expected to be far more difficult to resolve since the issues separating the warring parties would not disappear through any type of settlement.

\section{Findings}

I created this dataset to answer two questions: Why do civil wars rarely end in lasting negotiated settlements, and what conditions ultimately lead to negotiated solutions to these wars? My goal was to see which of the proposed hypotheses could best predict whether a civil war would end through a negotiated settlement or whether fighting would continue until one side or another won a decisive victory. To do this, a simple Pearson correlation coefficient or cross-tab analysis was used to determine which variables were most strongly related to settlement and which had little or no effect (see Table 3, discussed later). ${ }^{37}$

Overall, the single most successful explanation for why civil war negotiations failed was the credible-commitment argument. ${ }^{38}$ Once adversaries agreed to negotiate, every case where a third-party stepped in to guarantee a treaty resulted in a successful settlement (Table 2 summarizes the methods of resolution for civil wars with outside security guarantees). Outside powers guaranteed Lebanon's agreement in 1958, the Dominican Republic's “Act of Dominican Reconciliation," the Riyadh Agreement in Lebanon (1976), the Addis Ababa Agreement in Sudan (1972), the Lancaster House Agreement in Zimbabwe (1979), and the Tela Agreement in Nicaragua (1989), and all brought peace. Only two civil wars reached a successful settlement without an outside guarantee (Colombia in 1958 and Yemen in 1970), and the details of these two exceptions tend to confirm the rule.

Although Colombia and Yemen did reach settlements without outside guarantees, they were also the only two wars where the opposing parties could not launch surprise attacks against each other. Both wars were fought by relatively uncommitted armies whose loyalties could be procured by the highest bidder; the warring parties themselves did not have organized partisan forces at their command. In Colombia the

37. It should be emphasized that this analysis is based on the universe of all cases of civil wars between 1940 and 1990 and that, because of this, tests of statistical significance might be deemed inappropriate. In other words, one could ask why-if we are looking at the entire universe of nontrivial civil wars and not a sample of them-we should use a statistical test of significance to arbitrarily separate valid hypotheses from the rest? I have chosen to include statistical significance criteria because the inexact nature of the coding process and the limited time period suggest that not all inferences from the data will be wholly accurate. Since there is no way of estimating any possible errors in the data, I include conventional tests of statistical significance as a reasonable measure of the validity of each of the hypotheses.

38. These tests were also repeated using a multivariate logit regression. This analysis generally supported the conclusions of this article, however, the small number of cases caused problems with the logit estimating procedure. Specifically, the strong correlation between guarantees and successful settlement created a null set (there were no cases where security guarantees were offered and the settlement failed), which the logit estimating procedure had difficulty incorporating. Details of this analysis, therefore, were excluded from this article. 
Table 2. Civil wars with outside security guarantees and their method of resolution

\begin{tabular}{lccr}
\hline Type of guarantee & Decisive victory & Successful settlement & Row total \\
\hline No guarantee & $33(94 \%)$ & $2(6 \%)$ & $35(100 \%)$ \\
Weak guarantee & 0 & $1(100 \%)$ & $1(100 \%)$ \\
Moderate guarantee & 0 & $3(100 \%)$ & $3(100 \%)$ \\
Strong guarantee & 0 & $2(100 \%)$ & $2(100 \%)$ \\
Column total & $33(80 \%)$ & $8(20 \%)$ & $41(100 \%)$ \\
\hline
\end{tabular}

Chi-square $=10.43 ;(p=.015)$.

national army remained relatively uninvolved in the fighting and allowed the war to be fought by small bands of armed peasants. In Yemen, the Royalist rebels had no regular army. In order to fight, "tribal forces had to be assembled by negotiation with the shaikhs for each contemplated operation of any size." ${ }^{39}$ Thus, once the Conservatives and Liberals in Colombia and the Royalists and Republicans in Yemen agreed to compromise, they did not have to demobilize and integrate separate, partisan military corps. They simply bought the loyalty of either the powerful Colombian generals or the Yemeni tribes and in this way obtained fairly neutral forces. In short, these adversaries could successfully cooperate because they did not need to pass through a vulnerable demobilization and reintegration period. ${ }^{40}$

Close scrutiny of the other cases confirmed the strong effect that security fears had on settlement. In almost every civil war negotiation, final deliberations were filled with skeptical pronouncements about future security. Nigeria's Ibo population refused to sign a cease-fire agreement because they feared the government would massacre them, and the government refused to sign because they believed "that Ojukwu and his foreign backers will certainly use the cease-fire pause to re-arm and prepare for a bloodier conflict in which more innocent lives will be lost." ${ }^{41}$ Neither side trusted that the other would honestly abide by the terms.

In case after case belligerents eventually walked away from the bargaining table if an outside power did not step forward to monitor and enforce a peace treaty. When asked by a reporter if his demand for white control over the police and army during the transition was a make-or-break issue, Ian Smith replied: "Yes, it is, because if the African side goes back on this agreement, then we won't be seeing an interim government any time soon." 42 And when asked if the British had made "a crucial conces-

39. An excellent account of this war can be found in Stookey 1978, especially $243-45$ and 258.

40. Colombia's Conservative and Liberal parties also settled their differences using a very rigid and unique power-sharing arrangement. Their agreement called for a 50-50 division of political positions and an alternating presidency. Each party knew exactly how much political power they would receive. This also enhanced their sense of future security.

41. Stremlau 1977, 126.

42. Interview with Ian Smith, October 1976, in Baumhoegger 1984, vol. 2, 176. 
sion" by stationing British and Commonwealth forces in the assembly areas with the Patriotic Front troops, Robert Mugabe, head of the African rebels, echoed:

Yes. We welcomed that because it was the really vital element and it prevented the Rhodesian forces, you see, supported by the South African forces-who were in the country, don't forget-from attacking our assembly points. There were nasty incidents here and there. Yes, that was really vital. ${ }^{43}$

In his words, "it would be ridiculous for the settlers who are murdering the Zimbabweans to be intrusted with [our] security during the crucial transitional period." 44 He made it clear that the Patriotic Front "would rather prefer Ian Smith having 100 percent representation in Parliament and we having the army controlling, than having majority in Parliament with Ian Smith having the army, you see. That's not transference of power at all." 45

Even if an acceptable military settlement was reached (as it was between the Chinese Communists and the National government in 1945), neither side agreed to sign without some type of outside guarantee. If, however, peacekeeping forces were already in place but were withdrawn after a settlement was reached, as they were in Laos after the 1973 cease-fire and in Vietnam after the 1975 Paris peace talks, fighting always resumed shortly thereafter. Since the outside state had no intention of maintaining any commitment beyond a certain, often declared, date, its military presence had no positive effect on the success of negotiations. In the end, the ultimate success of a peace treaty seemed to rest on a third-party's desire to become involved and remain involved after a treaty was signed.

The relationship between security guarantees and settlement was clear. It was more difficult, however, to determine if the strength of a guarantee affected the likelihood of success since settlements always succeeded when outside guarantees were offered. Closer inspection, however, revealed an interesting pattern. Weak guarantees were generally offered in wars with very high costs and were usually offset by extensive internal power-sharing arrangements. Peace agreements that allowed the individual adversaries to retain as much independent strength as possible - in the form of political representation, veto powers, and a military balance in the national forcesrequired only weak external security guarantees in order to succeed. Conversely, outside guarantees tended to be strongest in less bloody wars with low costs, and treaties with vague or undeveloped political arrangements. Peace agreements that included few political guarantees for future political participation (or only the promise of elections) and unequal representation of groups in the national army required the strongest external guarantees in order to succeed. In these cases, the belligerents seemed far less certain of their own abilities to deter renewed war.

This inverse relationship between the strength of security guarantees and the extent of postwar internal political and military arrangements becomes clear when the

43. Interview with Mugabe, in Charlton 1990, 130-31.

44. "Report on R. Mugabe's Reaction to I. Richard's New Proposals 12/24/76," in Baumhoegger 1984, vol. 2, 236.

45. Interview with Mugabe ca. 11-14 May 1977, in Baumhoegger 1984, vol. 3, 328. 
actual treaties are compared. The settlement to end the Sudanese civil war was underwritten by the weakest guarantee of this study. Yet, in this case, Ethiopian Emperor Haile Selassie's fairly thin promise to the Sudanese rebels that "his government was committed to their security" and his personal guarantee that Anya Nya returnees would not suffer reprisal or repression were supplemented by some of the most detailed federal provisions of any settlement. ${ }^{46}$ Unlike many of the other peace accords, the Addis Ababa agreement to end the Sudanese war maintained very clear political and military distinctions between the fighting factions of the North and South. The new constitution guaranteed the continued existence of a southern regional government and gave the South enough tax revenue to survive without help from the wealthier North. More importantly, the accord was able to fashion a national army that preserved the armed strength of both factions. Under the terms of the peace accord, the southern command of the new national army would be equally divided between officers and soldiers from both the North and the South. ${ }^{47}$

These detailed and fairly balanced terms can be compared with the very weak political and military arrangements included in the 1958 and 1976 agreements to end the two civil wars in Lebanon. The 1958 agreement only arranged for the creation of a coalition cabinet consisting of two government and two opposition leaders; two members of the new cabinet would be Muslim and two members would be Christian. This treaty was backed by fourteen thousand U.S. troops who were stationed on the ground to ensure that fighting stopped. The 1976 Lebanese agreement was similarly weak; it only dealt with "the military and security aspects of the civil war and made no reference to the political and religious differences between the opposing Lebanese factions." ${ }^{48}$ This "weak" treaty was underwritten by an exceptionally strong Arab "deterrent" force.

The three remaining cases with outside guarantees fall somewhere in between these two extremes. Nicaragua (1989), Zimbabwe (1979), and the Dominican Republic (1965) all had extensive political and military power-sharing arrangements, and all were underwritten by moderate guarantees. Nicaragua's August 1989 Election Agreement called for free and open democratic elections and promised to create twenty-three self-governing development zones that the Contras could occupy and police on their own. These zones comprised 20 percent of the country. Numerous arrangements were also made to ensure the safest possible demobilization. Demobilization was asserted to be voluntary, and Contras who did not wish to participate would allegedly not be disturbed. Those who did decide to demobilize could gather at five security zones that would be controlled by ONUCA (United Nations Group in Central America); all Sandinista security forces would be withdrawn from within twenty kilometers of these areas. In return, the Sandinistas were offered an important military concession. After losing the election to Violeta Chamorro, leader of the opposition, Daniel Ortega was allowed to retain his position as commander-in-chief

48. Keesing's Contemporary Archives, 31 December 1976, 28123. 
of a re-formed army. This promised to safeguard the Sandinistas against renewed Contra attack. These fairly extensive internal security arrangements were then supplemented by 260 unarmed UN peacekeepers and 800 armed Venezuelan paratroopers.

Zimbabwe had a similar mix of internal and external security arrangements. Black Zimbabweans were offered one-man, one-vote elections in a country where they represented 97 percent of the population. In addition, Rhodesian civilians would be required to surrender their vast private armory of weapons, certain Rhodesian military and paramilitary units would be disbanded, a new civil police would be formed, and white South African forces currently stationed in Rhodesia would not be allowed to interfere in the transition. Finally, assembly points for demobilizing Patriotic Front soldiers would be located near their operation areas and far away from the Rhodesian army bases. This meant that many assembly areas would be located near Mozambique and Zambian borders and thus offer a quick escape should the assembled soldiers be attacked. In return, white Rhodesians were guaranteed 20 percent of the seats in the lower house of Parliament, they were allowed to retain control over the Rhodesian air force, and South African forces were allowed to remain on Zimbabwean soil. Most importantly, however, these white settlers were permitted to retain dual citizenship with Britain, which offered them their own quick escape should they themselves be threatened. Despite these assurances, the Patriotic Front still only signed the Lancaster House Agreement after Britain agreed to send twelve hundred Commonwealth forces to Zimbabwe and agreed to station them there until the new government was established.

In short, a durable settlement, one that will last even after outside forces withdraw, requires more than temporary police protection. Outside forces are necessary to get the opponents through the tricky transition period, but an effective long-term equilibrium must also be established. Governments and rebels were very concerned with specific power-sharing arrangements during negotiations, although these were not the decisive issues over which negotiations hung. Adversaries were able to enhance their own sense of security through a number of explicit treaty provisions (such as constitutional guarantees, legal protections, and well-balanced security designs). It is important to remember, however, that even the most extensive internal arrangements were not enough to completely alleviate the otherwise intense security dilemma. The Nigerian government promised the Ibos general amnesty, offered them a fair share of employment in federal public services, and promised that police units in Ibo areas would consist mostly of persons of Ibo origin, but this did little to reduce Ibo fear of postwar persecution. Without an external guarantor, this offer had little impact on negotiations, and it eventually failed to produce a settlement. No matter how brutal the war or how generous the terms, the two sides could not succeed on their own.

How well did the other theories predict success? Of all the other hypotheses, only one was able to predict civil war outcomes with any real consistency. The correlation coefficients presented in Table 3 show some support for a link between duration, stalemate, battle deaths per population, and successful settlement. In other words, as wars became more costly, the possibility of a successful settlement did increase some- 
Table 3. Possible causes of civil war settlement (all forty-one civil wars, 1940-90; Pearson correlation coeffõcient analysis)

Outcome (victory or settlement) ${ }^{\mathrm{a}}$

Security guarantee

Costs

Duration

Stalemate

Magnitude

Intensity

Divisibility

Goals

Population/resource distribution

Mediation

Identity

Ethnic

Religious
.841

.327

.381

.369

$-.184$

$-.060$

$-.055$

.258

.089

.267
$.000 * *$

$.042 *$

$.014 *$

$.025 *$

.290

.710

.744

.104

.580

.091

${ }^{a}$ Outcome is coded 1 for successful negotiated settlement and 0 for decisive victory. All the independent variables are coded so that a positive relationship conforms to the hypothesis.

$* * p<0.01$ (two-tailed).

$* p<0.05$.

what. All the other variables-divisibility, mediation, and identity-seemed either completely unrelated or only very weakly related to the outcome of civil wars.

As illustrated in Table 3, "costs" did seem to influence civil war outcomes. Longerthan-average wars were more likely to end in negotiated settlements than were short wars $(r=.327 ; p=.042)$, negotiations were more likely to succeed if a military stalemate existed on the battlefield $(r=.381 ; p=.014)$, and wars with greater than median battle deaths per population tended to reach successful settlements more often than those with lower death rates $(r=.369 ; p=.025)$. Clearly, these costs exacted a toll on the population and encouraged their leaders to reconcile. The only measure of costs that was not closely linked to outcome was intensity $(r=-.134$; $\mathrm{p}=.290$ ). More intense wars were no more likely to end in successful settlements than in decisive victories. One explanation might be that intense wars represent those conflicts where one side is making rapid military gains and therefore has no reason to compromise. If this were the case, then very intense wars should actually be negatively correlated with successful settlement. Table 3 does show some support for this conclusion.

Although the findings did offer some support for the cost hypothesis (hypothesis 2), it still could not predict successful settlement as well as outside security guarantees. Duration, stalemate, and battle deaths were clearly related to the outcome of these wars, but they were certainly not the crucial element in the ultimate outcome of 
the war. Only five out of fourteen long wars (35 percent) ended with a successful settlement, only three out of five military stalemates ( 60 percent) ended in successful settlement, and only five out of eighteen of the more brutal wars (28 percent) ended in settlement. By contrast, every case with a security guarantee ended successfully.

The data offered little or no support for the other hypotheses. As illustrated in Table 3, no identifiable relationship exists between divisibility and successful settlement, and only a very weak connection exists between mediation and success, and ethnicity and success; neither of which was statistically significant.

Contrary to the predictions of hypothesis 3 , neither divisibility nor goals had any effect on the outcome of a civil war. Separatist wars or wars with easily divisible stakes were no more likely to reconcile than wars where partition was impossible. Secessionists settled in only one of seven separatist wars, and in this case the Sudanese chose federation rather than territorial partition. The more objective measure of "divisibility" yielded the same results $(r=-.055 ; p=.744)$. Only two of the ten "highly divisible" cases (Sudan and Lebanon) reached a negotiated solution, and, once again, both rivals chose to maintain the territorial integrity of the original states. In contrast, four out of the twenty-three cases deemed "impossible" to partition actually reached a settlement (Colombia, the Dominican Republic, Yemen [1970], and Nicaragua [1989]).

This finding leads to an interesting observation. The credible-commitment theory of civil war resolution implies that partition should be a viable option for adversaries wishing to settle since it would circumvent the fatal problem of military disengagement. The intense security dilemma that undermines cooperation should not hold in cases where the combatants retain their armed forces. As we just saw, however, secessionist movements were no more amenable to successful settlement than were nonsecessionist wars. Governments rarely allowed sections of their territory to be lopped off in order to either avoid or shorten civil wars. Why? One could argue that governments view separation as a decisive victory for the rebels, not as a compromise. Yet governments and rebels should be able to come up with solutions that do not make it appear as if the government simply capitulated to the secessionist's demands. The government, for example, could relinquish a portion of the desired territory in return for economic compensation. In this way, the rebels would obtain their independence without forcing the government to set a precedent for easy accommodation. Perhaps a better explanation is that states reject separation as a viable solution because their reputation for resolve is intricately tied to their ability to defend and maintain their territory. ${ }^{49}$ Once it becomes clear that governments can no longer defend their own sovereign territory, they become attractive targets for any domestic or international foe. No government, therefore, can afford to part with territory even if it would increase the likelihood of ending a long and costly war. In short, although one would expect groups to embrace partition as an easy way out of domestic conflagrations, they simply do not view it as a satisfactory alternative to war.

49. This argument would follow from Thomas Schelling's discussions of reputation; see Schelling 1980, especially chap. 2. I am indebted to Jack Snyder for pointing out this connection. 
The data also showed only a weak link between mediation and successful settlement. Although wars in which a mediator was present were slightly more likely to end in a successful settlement, the relationship as shown in Table 3 was very weak $(\mathrm{r}=.258 ; p=.104)$. Only half of the successful peace treaties even had a mediator present. Colombia, Lebanon (1958, 1976), and Nicaragua (1989) all reached successful settlements without the aid of a direct intermediary, whereas mediators in twentysix other attempts failed to reach settlements. Diplomacy might make the bargaining process less arduous and allow the parties to find a solution sooner than otherwise, but such interventions did not affect the actual outcome of war.

But why would so many people insist on the importance of mediation? Two reasons come to mind. First, it is easy to claim that negotiations failed due to poor mediation and that others succeeded because diplomats expertly pulled all the right strings. Such post hoc explanations are never wrong. Second, this argument appears compelling because the appearance of mediators frequently coincides with the offer of outside security guarantees. Mediators often deliver security guarantees and therefore tend to appear in cases where settlements succeed. But by concentrating on mediation, these explanations have overlooked the real mechanism at work: mediators are only as effective as the guarantees their home states are willing to offer. Thus, the success of the Lancaster House Conference had less to do with Lord Carrington's skill, as most people argue,$^{50}$ than with the treaty guarantees Britain was willing to extend.

Finally, the supposedly more intransigent "identity" wars also did not act as predicted. Wars with strong ethnic underpinnings appear to be no more difficult to resolve than those fought over nonidentity issues $(r=.089 ; p=.580)$. And only very weak support was offered for the connection between religious wars and the absence of settlement $(r=.267 ; p=.091) .{ }^{51}$ Contrary to expectations, only 17 percent of the nonidentity wars (five out of twenty-nine) were successfully resolved, whereas a quarter of the cases (three out of twelve) where ethnicity was a central feature of the conflict actually found a successful settlement. In short, negotiated solutions to civil wars occurred between adversaries with very different racial, tribal, and religious differences; Sudan, Lebanon, and Zimbabwe were all driven by ethnic or religious issues, yet all ended in compromise. And settlements failed to emerge in wars with no ethnic or religious underpinnings. These findings directly challenge much of the conventional wisdom that claims that ethnic conflicts are somehow averse to settlement and show instead that fear and insecurity can interpose themselves on any conflict, no matter what the original makeup of the combatants and no matter what their original grievances.

The "identity" explanation most likely falls short because ethnic and religious differences emerge in interstate wars and make their agreements equally difficult to attain. Enemies will always be demonized and their unique qualities portrayed as evil and barbaric. Yet interstate opponents are able to overcome this hatred. Vital beliefs

50. See Low 1985; Stedman 1991; Davidow 1984; and Vance 1983.

51. Two recent quantitative studies had similar findings; see Licklider 1995; and Mason and Fett 1996. 
and emotions are often altered through positive propaganda, economic incentives, or simple socialization. They also sometimes mellow as other values come to the fore. As long as identity is used and manipulated to sustain all war movements, it cannot account for the discrepancy between international war and civil war resolution.

\section{But Does This Really Tell Us All We Need to Know?}

A number of challenges can be leveled at these findings. Although the evidence seems to offer clear support for the credible-commitment theory of civil war resolution, one could argue that guarantees only emerge under the most propitious circumstances. Outside states only offer guarantees in those civil wars where negotiations are already underway and therefore most likely to succeed. If this is true, then the seemingly powerful correlation between outside security guarantees and successful settlement could be spurious - merely the result of a selection effect.

Two tests were designed to check whether security guarantees had an independent effect on adversaries' decisions to sign and implement treaties. First, the original dataset was broken down into those civil wars in which negotiations occurred during their term and those in which they did not. The competing hypotheses were then retested against only those seventeen cases in which negotiations took place..$^{52}$ In this way, variables that were present in all forty-one civil wars (such as identity and divisibility) would have an equal opportunity to affect the outcome as those variables present only after negotiations commenced (such as mediation and guarantees). Would mediation and security guarantees still vary with the success and failure of negotiations when one looked only at those cases where combatants had already begun to talk?

In the second test, each of the individual cases in which settlements were reached was examined in greater detail. If guarantees were simply offered in cases that would have succeeded on their own, domestic adversaries should have signed and implemented agreements as soon as mutually acceptable terms to their underlying grievances were reached. No discussion should be found over the need or desire for outside guarantees.

As it turns out, both tests confirmed the strong correlation between outside security guarantees and successful settlement. When the seventeen cases with negotiations were analyzed separately three intriguing results appeared. First, as shown in Table 4 , security guarantees were still strongly related to successful outcomes $(r=$

52. Why not just analyze this subset of seventeen cases in the first place? Testing the competing hypotheses against a smaller subset of cases could have introduced an even more problematic selection bias. First, excluding civil wars simply because the belligerents did not attempt negotiations would be like excluding all cases where the dog did not bark. In other words, looking only at those wars where negotiations were attempted could rule out important cases where the belligerents knew that negotiations would have no chance for success and therefore did not even try. Second, a number of hypotheses (such as duration of war, battle deaths, divisibility, and identity) predicted successful settlement based on conditions that occurred during all wars, not simply during negotiations. Given this, I considered it necessary to look at all forty-one cases first and then perform subsequent secondary analysis on the seventeen cases where negotiations occurred. In this way I controlled for both types of selection bias. 
Table 4. Possible causes of civil war settlement (seventeen civil wars with negotiations, 1940-90; Pearson correlation coeffõcient analysis)

Outcome (victory or settlement) ${ }^{\mathrm{a}}$

Security guarantee

Costs

Duration

Stalemate

Magnitude

Intensity

Divisibility

Goals

Population/resource distribution

Mediation

Identity

Ethnic

Religious
.783

.019

.491

.016

$-.465$

.022

$-.051$

$-.056$

.044

.312
$.000 * *$

.942

$.045 *$

.959

.109

.935

.847

.832

.868

.225

${ }^{a}$ Outcome is coded 1 for successful negotiated settlement and 0 for decisive victory. All the independent variables are coded so that a positive relationship conforms to the hypothesis.

$* * p<.01$ (two-tailed).

$* p<.05$.

$.783 ; p=.000)$. Again, in every case in which a guarantee was offered, the two sides managed to reach and implement a lasting negotiated settlement. When no guarantee was offered, negotiations almost always broke down. Second, it became clear that the conditions necessary for negotiations to begin were not the same as the conditions necessary for negotiations to succeed. Whereas the duration of war and its magnitude (battle deaths per one thousand population) were significantly correlated with the outcome of the war when all forty-one cases were analyzed, when the seventeen cases of negotiations were analyzed separately these costs no longer had any significant effect on the ultimate success of these talks $(r=.019, p=.942$ for duration; and $r=.016, p=.959$ for magnitude). This suggests that duration and magnitude might have encouraged leaders to begin negotiations, but once talks began these "costs" were not enough to ensure final success. Third, military stalemate proved the only variable other than security guarantees that helped predict successful outcome in cases where negotiation occurred $(r=.491 ; \mathrm{p}=.045)$. In short, when the hypotheses were tested against the subset of seventeen cases experiencing negotiations, it became clear that high costs were a necessary condition for negotiations to begin, but security guarantees (to a greater extent) and military stalemate (to a lesser extent) were then necessary for these talks to succeed.

Why does a stalemate seem to affect the success of negotiations? I would argue that stalemates impart important information to groups nervous about their future. 
Military stalemates indicate that opponents are fairly evenly matched and cannot be easily overpowered. They also indicate a defensive advantage in the military contest. During these times groups are well-prepared to defend against attack, and this makes both successful aggression and surprise attack unlikely. Finally, stalemates also tend to bestow relatively equal bargaining power on the adversaries and thus promise a more equal distribution of power in any new government. Each of these conditions seems to create additional confidence in the long-term viability of an agreement and helps reduce fears of future exploitation..$^{33}$

The second test also corroborated the strong link between security guarantees and successful settlement. The Uganda Peace Accord of December 1985 created a new national army, divided leadership positions in the military council between the government and the rebels, and called for further political power sharing. Having resolved these tricky military and political issues, one would have expected this accord to flourish without the need for additional security guarantees; all the terms of the accord were in place. But security guarantees were crucial to both the final acceptance and the subsequent failure of the treaty. Kenya, Tanzania, Britain, and Canada were asked to establish a peacekeeping force to monitor the cease-fire, but Britain and Canada declined to participate. As a result, the terms were never implemented. Chad's Reconciliation Accord followed a similar pattern. Signed in August 1979, it called for the demilitarization of the capital, a general amnesty, a broad-based transitional government, and the dissolution of all armed forces. A neutral peacekeeping force from Guinea, Benin, and Congo was promised to enforce the cease-fire. This case is interesting because the government of "national unity" was actually established in November 1979. Unfortunately, the neutral African force did not arrive when scheduled, and no other terms were ever implemented. The new government broke down by March 1980, and the war resumed until the guerrillas eventually won a decisive victory seven years later. The importance of enforcement, therefore, should not be underrated. In most cases, adversaries were far more intransigent about basic security issues during the transition period than they were over multiparty rule, land reform, or majority rule. In many cases negotiations followed the same timetable: the political and economic issues were settled first, followed by the security arrangements. These were usually the final and most difficult issues to work out.

The strong evidence offered for the importance of third-party security guarantees and against the divisibility, identification, and mediation hypotheses suggests that a uniquely intense security dilemma really does hinder negotiation in civil wars. As many people have argued, adversaries are encouraged to bargain when the costs of continuing to fight become prohibitive. Yet high costs are not enough to convince them to sign a highly risky settlement without added assurances from the outside. Ultimately, it was the outside security guarantees that convinced these adversaries to sign.

53. For an excellent discussion on the effects of the distribution of power on settlement, see Wagner 1994. 


\section{Conclusions}

The empirical results presented in this article are striking: between 1940 and 1990 enemies in civil wars almost always failed to reach successful negotiated solutions to their conflicts unless an outside power guaranteed the safety of the belligerents during the ensuing transition period. This fact offers very strong support for the crediblecommitment theory of civil war resolution. Adversaries seem unable to credibly promise to abide by the terms of a treaty that by its very nature offers enormous rewards for cheating and enormous costs for being cheated upon. The results of the study also offered some support for the cost-benefit hypothesis of war termination. The duration and magnitude of a war did seem to affect the onset of negotiations, and a military stalemate did seem to influence when these negotiations would then succeed.

What implications do these findings have for international relations theory? The fact that both identity and the divisibility of stakes have no effect on either the desire to negotiate or the success of negotiations is a blow to those who believe that ethnic conflicts act fundamentally differently from other types of internal war and therefore require more drastic solutions, such as partition. Not only does ethnicity not appear to be an issue in whether or not adversaries will compromise, but partition also appears to be a particularly unacceptable solution for incumbent governments. This finding should temper claims that "ethnic" conflicts can only be resolved by dividing groups into separate, homogeneous regions. On the other hand, the weakness of the mediation hypothesis warns against relying too strongly on skilled diplomacy as the best way to help end civil wars. Mediation might be relatively cheap and easy, but simply providing better information and better lines of communication between domestic enemies does not appear sufficient to overcome severe security dilemmas. Without corresponding security guarantees, mediation cannot convince groups to implement treaties.

The significance of outside enforcement in civil war resolution, however, says much about group behavior in competitive situations. First, security dilemmas can emerge in any anarchic situation, even at the substate level and even for short amounts of time. Its damaging effects are not limited to states in the international system. In fact, in the face of a completely anarchic transition period, incumbent governments and rebels act exactly like states in the international system: they resist collective security and rely instead on their own self-help systems.

Second, although groups react similarly to the conditions of anarchy, this study also reveals that groups are not equally able to control its divisive effects. The situation in which anarchy emerges greatly affects the probability for successful cooperation. If groups can reduce their vulnerability and use strategies of reciprocity to enforce compliance, then cooperation will have a far greater chance to prosper. Yet if groups cannot do this, they will find it virtually impossible to design credible treaties without outside assistance.

Third, the relationship between the strength of security guarantees and internal power-sharing arrangements indicates the importance of institutions for the long- 
term success of any peace agreement. Security might have been the most immediate problem governments and rebels faced when attempting to end their wars, but ultimately they cared greatly about future political arrangements. Thus, it seems both security guarantees and institutional arrangements for power sharing were necessary to ensure stable and durable settlements. In the end, both outside enforcement and inclusive institutions appear necessary for civil wars to end short of decisive military victories. While enforcement is crucial to the short-term implementation of a peace treaty, especially under conditions of severe helplessness, institutions and creative constitutional contracts are crucial for long-term success. Thus, a mixture of force and institutions provides the desired outcome: long-term peace.

\section{Implications}

Although even the best quantitative research is never sufficient to make decisions in complex, real-world situations, the findings presented in this article could offer important guidelines to policymakers searching for effective ways to help end civil wars.

First, and most importantly, the only type of peacekeeping that appears to help end a war is that which is backed by a promise to use force. Observers or unarmed peacekeepers with no military backup will have little positive effect on either negotiations or treaty implementation. In fact, these "traditional" peacekeepers will most likely be placed in unstable situations prone to spiral back into violence. Even in the most promising situation-for example, when belligerents have signed a detailed peace agreement - the war will most likely resume, and unarmed peacekeepers will suffer.

Second, if a state wishes to limit its involvement or share responsibility by working through a multilateral organization, it will be much more difficult to make a credible commitment to enforce the settlement, and this type of involvement will more likely fail to foster an agreement. A guarantee will only be as effective as the political will of its backers. Thus, any hesitation or wavering by member states will signal irresolution to the already anxious adversaries and ultimately undermine enforcement operations.

Third, the historical record also indicates that successful guarantors should be willing to stay through the establishment of the new government and a new national army. Intervention will have little effect on facilitating a long-term settlement if a state remains involved only through the signing of a peace treaty. If a state ends its involvement prematurely, it cannot perform the necessary function of enforcing the treaty, and the settlement will fall apart. Negotiations should be viewed as the beginning of the peace process, not the end.

Fourth, strict neutrality by the third party also does not appear necessary. The outside guarantor in most cases was not a wholly unbiased participant, yet this did 
not seem to reduce their effectiveness. ${ }^{54}$ In fact, the Zimbabwe case suggests that when an enormous power disparity exists between the adversaries, a somewhat biased third party in favor of the minority group can actually enhance feelings of security. The fact that Britain was viewed as prejudiced in favor of the white Rhodesians seems to have increased white confidence in their own survival.

Another surprising finding was the negative effect disarmament had on adversaries' sense of security. Rather than reassure former adversaries that they would not be attacked during the transition period, the demand to disarm actually increased their fear of attack. In most cases, adversaries had no illusions about their former enemy's ability to hide or procure weapons if they so chose. Allowing each side to retain observable weapons enhanced their feelings of security and made them more likely to follow through with treaty promises.

Sixth, a striking implication of this study is that alternatives do exist to prolonged and extensive intervention; under certain conditions, outside states can avoid committing large numbers of forces to a foreign country and still facilitate cooperation. Fewer enforcement troops will be needed if extensive internal power-sharing arrangements have been designed and all parties are guaranteed an effective voice in the new government. If, however, one side can easily be shut out of power (as might happen in winner-take-all elections or peace treaties that leave future political arrangements vague or undefined), a stronger force will be required for such settlements to succeed. In short, limited security guarantees can be offset by more detailed internal arrangements, but even the most detailed political plans will require at least some type of outside guarantee.

Finally, two additional points should be emphasized. First, security guarantees are a necessary, not a sufficient condition for settlement. Guarantees in the face of an ongoing war where the combatants have no desire to negotiate are unlikely to succeed. States wishing to facilitate early solutions to civil wars must wait until the groups themselves desire peace before their promises of enforcement will have any positive effect. Second, one should keep in mind that negotiated settlements are not always the least costly solutions to civil wars since the rapid victory of one side over another can bring fewer casualties and longer peace over the long run. Nonetheless, some battles are clearly worth fighting for, as Lincoln's struggle against the U.S. South attests. In short, settlements do have the potential to put an end to enormous suffering, and negotiation sends an important message to the Milosevics of the world that internal aggression will not always be ignored by the international community. Moreover, compromise settlements offer a chance to institute multiparty democratic states in situations that might otherwise result in one-party authoritarian regimes. Negotiations during times of civil war, therefore, could be viewed as moments of great opportunity rather than as futile attempts to create collaborative regimes.

History, therefore, offers good and bad news to the international community. The good news is that outside intervention can end potentially bloody civil wars provided the intervening state is committed to guaranteeing the peace treaty and the two war-

54. This argument is also made by Betts 1994 . 
ring parties are in favor of a settlement. The bad news is that nonmilitary intervention, although politically more acceptable and financially less costly, is unlikely to accomplish much. It may provide a temporary solution, but it does not address the more fundamental issue of insecurity. It may stay the bloodshed temporarily, but, by definition, such intervention cannot enforce a peace, since maintaining any settlement and rebuilding a stable community occur only after a war is over. Outside powers can play a critical role in the resolution of civil wars, but only if they are willing to make a solid commitment and bear the necessary costs.

\section{References}

Assefa, Hiskias. 1987. Mediation of Civil Wars: Approaches and Strategies: The Sudan Conflict. Boulder: Westview Press.

Baumhoegger, Goswin. 1984. The Struggle for Independence: Documents on the Recent Development of Zimbabwe (1975-1980). Vols. 1-7. Hamburg: Institute of African Studies.

Bell, J. Bowyer. 1972. Societal Patterns and Lessons: The Irish Case. In Civil Wars in the Twentieth Century, edited by Robin Higham. Lexington: University Press of Kentucky.

Betts, Richard. 1994. The Delusions of Impartial Intervention. Foreign Affairs 73 (6): 20-33.

Burton, John W. 1987a. International Conflict Resolution Priorities. Forum. Peace Institute Reporter.

1987b. Resolving Deep-Rooted Conflict: A Handbook. Lanham, Md.: University Press of America.

Charlton, Michael. 1990. The Last Colony in Africa: Diplomacy and the Independence of Rhodesia. Oxford and Cambridge: Basil Blackwell.

Davidow, Jeffrey. 1984. A Peace in Southern Africa: The Lancaster House Conference on Rhodesia, 1979. Boulder: Westview Press.

Department of State. The China White Paper. Far Eastern Series 30. Stanford: Stanford University Press. Fearon, James. 1993. Ethnic War as a Commitment Problem. Unpublished paper, University of Chicago. 1994. Domestic Political Audiences and the Escalation of International Disputes. American Political Science Review 88:577-92.

1995. Rationalist Explanations for War. International Organization 49:379-414.

Holl, Jane. 1993. When War Doesn't Work. In Stopping the Killing: How Civil Wars End, edited by Roy Licklider. New York: New York University Press.

Horowitz, Donald L. 1985. Ethnic Groups in Conflict. Berkeley: University of California Press.

Ikle, Fred C. 1991. Every War Must End. 2d ed. New York: Columbia University Press.

Jervis, Robert. 1976. Perception and Misperception in International Politics. Princeton: Princeton University Press.

. 1978. Cooperation Under the Security Dilemma. World Politics 30:167-214.

1989. Logic of Images in International Relations. New York: Columbia University Press.

Kydd, Andrew. 1996. Escalation, Fear, and War. Unpublished paper, University of California, Los Angeles.

Lake, David, and Donald Rothchild. 1996. Ethnic Fears and Global Engagement: The International Spread and Management of Ethnic Conflict. Policy paper 20, Institute on Global Conflict and Cooperation.

Licklider, Roy. 1995. The Consequences of Negotiated Settlement in Civil Wars, 1945-1993. American Political Science Review 89:681-90.

Low, Stephen. 1985. The Zimbabwe Settlement, 1976-1979. In International Mediation in Theory and Practice, edited by Saadia Touval and I. William Zartman. Boulder: Westview Press.

Mason, T. David, and Patrick J. Fett. 1996. How Civil Wars End: A Rational Choice Approach. Journal of Conflict Resolution 40 (December).

Mercer, Jonathan. 1996. Reputation and International Politics. Ithaca, N.Y.: Cornell University Press.

Miall, Hugh. 1992. The Peacemakers: Peaceful Settlement of Disputes Since 1945. New York: St. Martin's Press. 
Mitchell, C. R. 1991. Classifying Conflicts: Asymmetry and Resolution. In Resolving Regional Conflicts: International Perspectives, edited by I. William Zartman. The Annals of the American Academy of Political and Social Science 518.

Modelski, George. 1964. International Settlement of Internal War. In International Aspect of Civil Strife, edited by James Rosenau. Princeton: Princeton University Press.

Pillar, Paul. 1983. Negotiating Peace: War Termination as a Bargaining Process. Princeton: Princeton University Press.

Posen, Barry. 1993. The Security Dilemma and Ethnic Conflict. In Ethnic Conflict and International Security, edited by Michael E. Brown. Princeton: Princeton University Press.

Randle, Robert. 1973. The Origins of Peace: A Study of Peacemaking and the Structure of Peace Settlements. New York: Free Press.

Rothchild, Donald, and Caroline Hartzell. 1993. The Peace Process in the Sudan, 1971-1972. In Stopping the Killing: How Civil Wars End, edited by Roy Licklider. New York: New York University Press.

Schelling, Thomas C. 1966. Arms and Influence. New Haven: Yale University Press. 1980. The Strategy of Conflict. Cambridge: Harvard University Press.

Small, Melvin, and J. David Singer. 1982. Resort to Arms: International and Civil Wars, 1816-1980. Beverly Hills: Sage Publications.

Stedman, Stephen John. 1991. Peacemaking in Civil War: International Mediation in Zimbabwe, 19741980. Boulder: Lynne Rienner Publishers.

Stookey, Robert W. 1978. Yemen: The Politics of the Yemen Arab Republic. Boulder: Westview Press.

Stremlau, John J. 1977. The International Politics of the Nigerian Civil War: 1967-1970. Princeton: Princeton University Press.

Touval, Saadia, and I. William Zartman, eds. 1985. International Mediation in Theory and Practice. Boulder: Westview Press.

Vance, Cyrus. 1983. Hard Choices: Critical Years in America's Foreign Policy. New York: Simon and Schuster.

Wagner, R. Harrison. 1993. The Causes of Peace. In Stopping the Killing: How Civil Wars End, edited by Roy Licklider. New York: New York University Press.

. 1994. Peace, War, and the Balance of Power. American Political Science Review 88:593-607.

Wai, Dunstan M. 1981. The African-Arab Conflict in the Sudan. New York and London: Africana Publishing Company.

Weingast, Barry R. 1994. Constructing Trust: The Political and Economic Roots of Ethnic and Regional Conflict. Unpublished paper, Hoover Institute.

Zartman, I. William. 1989. Ripe for Resolution: Conflict and Intervention in Africa. Oxford: Oxford University Press.

1993. The Unfinished Agenda: Negotiating Internal Conflicts. In Stopping the Killing: How Civil Wars End, edited by Roy Licklider. New York: New York University Press. 